Original Research Article

\title{
Efficacy of 5HT3 receptor antagonist ondansetron antidepressant activity in physical induced albino mice
}

\author{
Janardhan Marupaka ${ }^{1 *}$, Roopa B. ${ }^{2}$, Naveen Kumar T. ${ }^{3}$
}

${ }^{1}$ Department of Pharmacology, Rajiv Gandhi Institute of Medical Sciences (RIMS), Adilabad, Telangana, India ${ }^{2}$ Department of Pharmacology, RVM Institute of Medical Sciences and Research Centre, Laxmakkapally, Mugulu, Medak, Telangana, India ${ }^{3}$ Department of Pharmacology, Apollo Institute of Medical Sciences and Research, Hyderabad, Telangana, India

Received: 09 August 2018 Accepted: 31 August 2018

*Correspondence to:

Dr. Janardhan Marupaka, Email: marupaka.dr@gmail.com

Copyright: (C) the author(s), publisher and licensee Medip Academy. This is an openaccess article distributed under the terms of the Creative Commons Attribution NonCommercial License, which permits unrestricted noncommercial use, distribution, and reproduction in any medium, provided the original work is properly cited.

\begin{abstract}
Background: The objective of this study was to evaluate efficacy of 5HT3 receptor antagonist ondansetron antidepressant activity in physical induced swiss albino mice.

Methods: Study was placebo controlled, randomized laboratory based comparative study with prior permission of Institutional animal ethical committee. Experimental animals were divided in to seven groups as control (distilled water $10 \mathrm{ml} / \mathrm{kg}$ ), standard Fluoxetine two doses $(10 \mathrm{mg} / \mathrm{kg}$ and $20 \mathrm{mg} / \mathrm{kg}$ ) , test drug ondansetron three doses $(0.5 \mathrm{mg} / \mathrm{kg}, 1 \mathrm{mg} / \mathrm{kg}$ and $2 \mathrm{mg} / \mathrm{kg}$ ) and combinations of test and standard $(0.5 \mathrm{mg} / \mathrm{kg}+10 \mathrm{mg} / \mathrm{kg})$. The drugs were administered intraperitonium and antidepressant activity was recorded using physically induced depression models tail suspension test and despair swim test. Results: Ondansetron treated albino mice groups with dose dependent increase of $0.5 \mathrm{mg} / \mathrm{kg}, \quad 1.0 \mathrm{mg} / \mathrm{kg}$ and $2.0 \mathrm{mg} / \mathrm{kg}$ showed significant decrease in antidepressant activity and increase in catalepsy score when compared with fluoxetine $10 \mathrm{mg} / \mathrm{kg}$ and $20 \mathrm{mg} / \mathrm{kg}$. Combination doses showed stastically significant antidepressant activity.

Conclusions: The present study indicates ondansetron showed promising antidepressant activity due to its ability to modulate serotonergic system and has proved to be safe in the dose range of $0.5 \mathrm{mg} / \mathrm{kg}, 1 \mathrm{mg} / \mathrm{kg}$ and $2 \mathrm{mg} / \mathrm{kg}$ in mice.
\end{abstract}

Keywords: Antidepressant activity, Albino mice, Ondansetron, Physical induced

\section{INTRODUCTION}

Depression is extremely common, with up to $30 \%$ of primary care patients having depressive symptoms. Depression may be the final expression of genetic factors, developmental problems related to personality, childhood events and psychosocial stresses such as divorce, unemployment. Depression is marked by a sense of guilt and worthlessness. ${ }^{1}$
Approximately two-thirds of the depressed patients respond to currently available drug treatments (tricyclic antidepressants, selective serotonin inhibitors (SSRI's) etc), but the magnitude of improvement is disappointing and have side effects. Search for more effective drugs with few side effects is on.

Ondansetron is a selective 5HT3 receptor antagonist used as an antiemetic which showed potent antidepressant like effect and was evaluated for its efficacy in depression in 
few studies. ${ }^{2}$ Several pre-clinical (behavioural, neurochemical and genetic) studies have provided evidences linking 5-HT3 receptors and depression. So, in this study, an effort is made to investigate the antidepressant effect of ondansetron in physical induced models of albino mice in comparison to selective serotonin reuptake inhibitor fluoxetine. ${ }^{3}$

\section{METHODS}

The study was approved by Institutional animal ethical committee of Kamineni institute of medical sciences, narketpally, Andhra Pradesh. The study was placebo controlled randomised laboratory based comparative study on albino mice. Total of 42 albino mice (25-30 gm) procured from national institute of nutrition, Hyderabad were used. Animals were acclimatized to laboratory environment before being used in the study.

\section{Instruments and apparatus}

The standard methods for measuring antidepressant models like tail suspension test, despair swim test by physically induction described by Gerhard Vogel were used. $^{4}$

\section{Tail suspension test}

Tail suspension test is based on the principle that suspending mice upside down leads to a characteristic behaviour of immobility after initial momentary struggle. Animal was considered to be immobile when it did not show any movement of body and hanged passively, and the duration of immobility was recorded automatically for 6 min using a computerized device (Bioseb TST). Six mice were studied simultaneously. The test substances were administered i.p. $30 \mathrm{~min}$ before the test. The duration of immobility was comprised between 60 and $120 \mathrm{sec}$ in the vehicle control group.

\section{Despair swim test}

Despair swim test is based on the principle that forcing mice to swim in restricted space from which they cannot escape leads to a characteristic behaviour of immobility. This behaviour reflects a state of despair, which can be reduced by several agents that are therapeutically effective in human depression. Animals were individually placed in a cylinder (height $=40 \mathrm{~cm}$, diameter $=20 \mathrm{~cm}$ ) containing $13 \mathrm{~cm}$ water $\left(25^{\circ} \mathrm{C}\right)$ for $15 \mathrm{~min}$ on the first day of the experiment (session 1) and were then put back in the water $24 \mathrm{hr}$ later for a 5 -min test (session 2). The duration of immobility during the 5-min test was measured. The test substances were administered i.p. $24 \mathrm{hr}$, 4hr, and 30min before the test (session 2). A mouse was considered immobile when it remained floating in the water without struggling, making only minimum movements of its limbs necessary to keep its head above water. The duration of immobility was comprised between 60 and $120 \mathrm{sec}$ in the vehicle control group. ${ }^{5}$

\section{RESULTS}

\section{Tail suspension test}

Mean duration of immobility in animals treated with ondansetron doses $0.5 \mathrm{mg} / \mathrm{kg}, 1.0 \mathrm{mg} / \mathrm{kg}$ and $2.0 \mathrm{mg} / \mathrm{kg}$ was significantly reduced compared to animals in control group. Ondansetron $0.5 \mathrm{mg} / \mathrm{kg}(\mathrm{P}<0.02)$ has low efficacy when compared with $10 \mathrm{mg} / \mathrm{kg}$ standard fluoxetine $(\mathrm{P}$ $<0.03)$.

Ondansetron $1.0 \mathrm{mg} / \mathrm{kg}$ and $2 \mathrm{mg} / \mathrm{kg}$ showed significant decrease in immobility time when compared with fluoxetine $20 \mathrm{mg} / \mathrm{kg}$. The effect obtained due to combination of low doses of ondansetron $0.5 \mathrm{mg} / \mathrm{kg}$ and fluoxetine $10 \mathrm{mg} / \mathrm{kg}$ showed significant synergism (P $<0.04$, Table 2).

\section{Despair swim test}

There was significant reduction in immobility time in the animals treated with ondansetron doses $0.5 \mathrm{mg} / \mathrm{kg}$, $1.0 \mathrm{mg} / \mathrm{kg}$ and $2.0 \mathrm{mg} / \mathrm{kg}$ compared to control group (P $<0.05$, Table 1). Ondansetron $1 \mathrm{mg} / \mathrm{kg}$ and $2 \mathrm{mg} / \mathrm{kg}$ are more potent when compared with $0.5 \mathrm{mg} / \mathrm{kg}$ when compared with standard doses of fluoxetine $10 \mathrm{mg} / \mathrm{kg}$ and $20 \mathrm{mg} / \mathrm{kg}$. Low dose combinations of ondansetron and fluoxetine showed synergism $(\mathrm{P}<0.05$, Table 3$)$.

\section{Table 1: Division of groups, drugs, doses and route of administration.}

\begin{tabular}{|llll|}
\hline Groups & Drugs & Doses & Route \\
\hline 1 & Normal saline & $10 \mathrm{ml} / \mathrm{kg}$ & i.p \\
\hline 2 & Ondansetron & $0.5 \mathrm{mg} / \mathrm{kg}$ & i.p \\
\hline 3 & Ondansetron & $1.0 \mathrm{mg} / \mathrm{kg}$ & i.p \\
\hline 4 & Ondansetron & $2 . \mathrm{mg} / \mathrm{kg}$ & i.p \\
\hline 5 & Fluoxetine & $10 \mathrm{mg} / \mathrm{kg}$ & i.p \\
\hline 6 & Fluoxetine & $20 \mathrm{mg} / \mathrm{kg}$ & i.p \\
\hline 7 & Ondansetron+ & $0.5 \mathrm{mg} / \mathrm{kg}+$ & i.p \\
& Fluoxetine & $1.0 \mathrm{mg} / \mathrm{kg}$ & \\
\hline
\end{tabular}

Table 2: Comparison of immobility time in seconds $(\mathrm{Mean} \pm \mathrm{SE})$ in despair swim test.

\begin{tabular}{|ll|l|}
\hline Groups & Mean \pm SE & P value \\
\hline $\begin{array}{l}\text { Control (Normal Saline) } \\
10 \mathrm{ml} / \mathrm{kg}\end{array}$ & $174.50 \pm 5.16$ & 0.06 \\
\hline Ondansetron $0.5 \mathrm{mg} / \mathrm{kg}$ & $151.83 \pm 3.78$ & 0.03 \\
\hline Ondansetron $1.0 \mathrm{mg} / \mathrm{kg}$ & $76.00 \pm 1.52$ & 0.001 \\
\hline Ondansetron $2.0 \mathrm{mg} / \mathrm{kg}$ & $72.66 \pm 2.57$ & 0.0001 \\
\hline Fluoxetine $10 \mathrm{mg} / \mathrm{kg}$ & $126.16 \pm 4.18$ & 0.02 \\
\hline Fluoxetine $20 \mathrm{mg} / \mathrm{kg}$ & $106.16 \pm 2.57$ & 0.0001 \\
\hline $\begin{array}{l}\text { Ondansetron } 0.5 \mathrm{mg} / \mathrm{kg}+ \\
\text { Fluoxetine } 10 \mathrm{mg} / \mathrm{kg}\end{array}$ & $108.83 \pm 3.32$ & 0.04 \\
\hline
\end{tabular}

$\mathrm{P}<0.001$ is highly significant, $\mathrm{P}<0.05$ is significant.

The effect of untreated group showed characteristic behaviour of mobility and (at 30min, 60min, 90min and 
$120 \mathrm{~min})$ ondansetron pretreatment reduced the movement of body and hanged passively (30min, 60min, 90min and $120 \mathrm{~min})$ for different doses of ondansetron $(0.5 \mathrm{mg} / \mathrm{kg}$, $1.0 \mathrm{mg} / \mathrm{kg}$ and $2.0 \mathrm{mg} / \mathrm{kg}$ ) and fluoxetine $(10 \mathrm{mg} / \mathrm{kg}$ and $20 \mathrm{mg} / \mathrm{kg})$.

Table 3: Comparison of immobility time in seconds $($ Mean \pm SE) in tail suspension test.

\begin{tabular}{|lll|}
\hline \multicolumn{1}{|c|}{ Groups } & Mean \pm SE & P value \\
\hline Control (Normal saline) $10 \mathrm{ml} / \mathrm{kg}$ & $202.83 \pm 3.11$ & 0.06 \\
\hline Ondansetron $0.5 \mathrm{mg} / \mathrm{kg}$ & $139.83 \pm 2.65$ & 0.02 \\
\hline Ondansetron $1.0 \mathrm{mg} / \mathrm{kg}$ & $107.83 \pm 2.15$ & 0.001 \\
\hline Ondansetron $2.0 \mathrm{mg} / \mathrm{kg}$ & $105.16 \pm 2.97$ & 0.0001 \\
\hline Fluoxetine $10 \mathrm{mg} / \mathrm{kg}$ & $123.50 \pm 1.82$ & 0.03 \\
\hline Fluoxetine $20 \mathrm{mg} / \mathrm{kg}$ & $106.16 \pm 2.58$ & 0.0001 \\
\hline $\begin{array}{l}\text { Ondansetron } 0.5 \mathrm{mg} / \mathrm{kg}+ \\
\text { Fluoxetine } 10 \mathrm{mg} / \mathrm{kg}\end{array}$ & $108.83 \pm 3.32$ & 0.04 \\
\hline
\end{tabular}

\section{DISCUSSION}

Ondasetron potent 5HT3 antagonist used primarily to treat nausea and vomiting associated with cancer therapy because of their ligands located in area postrema. Greenshaw in 1992 has reported possible involvement of 5HT3 receptors in depression.6 Further ondansetron also effects both peripheral and central nervous systems via serotonin receptors (5HT3) involved in mood regulation (hippocampus or prefrontal cortex). ${ }^{7}$ The antidepressantlike effect of ondansetron may be explained by blocking the 5HT3 receptors which lead to increased 5HT or norepinephine levels. ${ }^{8}$ Further the Zifa E et al, reported that 5HT3 receptor sites are ligand gated ion channels which modulate the release of a number of neurotransmitters. ${ }^{9}$ The results obtained have been compared with the standard antidepressant drug fluoxetine. Also, the effect obtained due to combination of low doses of ondansetron $0.5 \mathrm{mg} / \mathrm{kg}$ and Fluoxetine $10 \mathrm{mg} / \mathrm{kg}$ was determined whether any synergism was there between two drugs. In tail suspension test and despair swim test, mean duration of immobility in animals treated with three doses of ondansetron was reduced which was statistically significant compared to control and standard. Ondansetron $2.0 \mathrm{mg} / \mathrm{kg}$ showed reduction in immobility time compared to standard fluoxetine $20 \mathrm{mg} / \mathrm{kg}$ indicating efficacy similar to fluoxetone.

\section{Pharmacokinetics of ondansetron}

Oral bioavailability is high due to low first pass metabolism and $\mathrm{t} 1 / 2$ of $8-12 \mathrm{hrs}$. $2 \mathrm{mg} / \mathrm{kg}$ dose is well tolerated with no clinical drug interactions has been noted. Common side effect of headache and dizziness has been demonstrated. ${ }^{10}$

\section{CONCLUSION}

Ondansetron doses $0.5 \mathrm{mg} / \mathrm{kg}, \quad 1.0 \mathrm{mg} / \mathrm{kg}$ and $2.0 \mathrm{mg} / \mathrm{kg}$ showed significant decrease in antidepressant activity in despair swim test and tail suspension test. These effects may be because of modulation of central monoaminergic neurotransmitter systems by blocking the post synaptic 5HT3 receptors. Further studies are required in experimental animals and humans to confirm its antidepressant activity.

Funding: No funding sources

Conflict of interest: None declared

Ethical approval: The study was approved by the Institutional Ethics Committee

\section{REFERENCES}

1. Maxine A, Papadakis, Stephen JM. Mood disorders. In: Current Medical Diagnosis and Treatment, $55^{\text {th }} \mathrm{Ed}$. New Delhi. McGraw Hill Education; 2016:1057.

2. Martin P, Gozlan H, Puech AJ. 5-HT3 receptor antagonists reverse helpless behaviour in rats. Eur $\mathbf{J}$ Pharmacol. 1992 Feb 25;212(1):73-8.

3. Ramamoorthy $\mathrm{R}$, Radhakrishnan $\mathrm{M}$, Borah $\mathrm{M}$. Antidepressant-like effects of serotonin type-3 antagonist, ondansetron: an investigation in behaviour-based rodent models. Behavioural Pharmacol. 2008 Feb 1;19(1):29-40.

4. Kalra BS, Tayal V, Chawla S. Antidepressant-like activity of tramadol in mice. Indian J Psychiatry. 2008 Jan;50(1):51.

5. Vogel HG. Antidepressant activity. Drug Discovery and Evaluation: Pharmacological Assays, edited by Vogel HG, $2^{\text {nd }}$ Ed. Germany: Springer - Verlag Berlin Heidelberg; 2002.

6. Greenshaw AJ. Behavioral pharmacology of 5HT3 receptor antagonist: acritical uptake on therapeutic potential. Trends Pharmacol Sci. 1992;14:265-70.

7. Bétry C, Etiévant A, Oosterhof C, Ebert B, Sanchez C, Haddjeri N. Role of 5-HT3 receptors in the antidepressant response. Pharmaceuticals. $2011 \mathrm{Apr}$ 7;4(4):603-29.

8. Blandina PA, Goldfarb JO, Walcott JA, Green JP. Serotonergic modulation of the release of endogenous norepinephrine from rat hypothalamic slices. J Pharmacol Experiment Therapeut. 1991 Jan 1;256(1):341-7.

9. Zifa E, Fillion G. 5HT receptors. Pharmacol Rev. 1992;44:401-58.

10. Tripathi KD. Antiemetic, Prokinetic and digestant drugs. Essential of Medical Pharmacology. $8^{\text {th }}$ Ed. New Delhi. Jaypee Brothers medical publishers;2018:716-717.

Cite this article as: Marupaka J, Roopa B, Kumar NT. Efficacy of 5HT3 receptor antagonist ondansetron antidepressant activity in physical induced albino mice. Int J Basic Clin Pharmacol 2018;7:2028-30. 